\title{
Behaving Like a Man? Incest, Lesbian Desire, and Gender Play \\ in $\underline{\text { Yde et Olive }}$ and its Adaptations
}

\section{Diane Watt}

In her recent book Love Between Women: Early Christian Responses to Female Homoeroticism, Bernadette J. Brooten explains that she uses the word "lesbian" "in its medieval sense of a woman who 'behaves like a man' (i.e., usurps the male cultural role) and 'is oriented toward female companionship for sex'" (17). ' There are some problems with this definition. It might be argued that the term "lesbian" was not employed widely (if at all) in the later Middle Ages."

Furthermore the notion of "sexual orientation"--which implies an essentialist attitude towards sexual identity--does not accurately reflect the fluid and pluralistic views on sexuality and sexual difference in circulation in the pre-modern age (Boswell, "Revolutions"). More importantly, this definition begs the question whether it is the lesbian's appropriation of all or just some aspects of the "male cultural role" which is seen to be disruptive.

One of the overarching arguments of Brooten's study is that although the idea of female same-sex unions may have been regarded with a degree of social acceptance by contemporaries, the transgression of gender roles was central to the condemnation of sexual relations between women by ancient and patristic writers. In this essay I intend to examine the applicability of this assertion to the medieval period by analyzing a fictional narrative about a marriage between women--the story of Yde-in its medieval and early modern French and English versions. I will address the questions of what it means for a woman to behave like a man in these texts and when this behavior is judged to be unacceptable. I will argue that, despite its socially-disruptive potential, female homoerotic desire is treated more sympathetically than the father-daughter incest with which it is paralleled, and to which, it is connected conceptually (father-daughter incest being an occasion when it is equally inappropriate for a man to behave like a man). Similarly, a troubled but tolerant attitude to female cross-dressing and transsexuality is conveyed by the shifting, conflicting and internally-inconsistent positions adopted by the writers of these narratives, who seem uncertain whether their hero(ine) is a man, or is behaving like one, or is simply behaving like an aristocrat. Indeed these texts reveal that inheritance laws and class structures play a crucial role both in the construction and containment of transgressive sexualities and gender play.

The primary focus of this essay will be on La chanson d'Yde et Olive, ${ }^{\text {iii }}$ a continuation, in verse, of the epic poem Huon de Bordeaux, found alongside that text and four other romances in the cycle in the fourteenth-century Turin manuscript. The story describes how the beautiful Princess Yde, the granddaughter of Huon of Bordeaux, is forced to flee the incestuous desires of her father, Florence, the King of Aragon. Disguised as a man, the princess escapes from her father's court and finally, after joining a band of mercenaries and running into trouble with some robbers, arrives in Rome. Once there, she enters the service of the Emperor and, having been dubbed by her new lord, performs great feats of chivalry against an invading Spanish army. The Emperor, unaware that she is not the man she passes as, rewards her with the hand of his daughter, who harbors feelings of love for the valorous knight. Initially Yde resists the Emperor's wishes, but eventually submits to his command to marry. After the wedding the couple embrace and when Olive proves too insistent in her desire, Yde feels compelled to tell her that she is a woman. Rather than reacting with horror, Olive is sympathetic to Yde's predicament and vows to remain true and keep her secret. Unfortunately their conversation is overheard and reported to the Emperor. Their lives are only saved by divine intervention--Yde receives a miraculous sex-transformation. Shortly afterwards he is crowned Emperor and eventually returns to Aragon, where he finds that his father is dead and the country in disorder. In the later versions, he is welcomed by his father, whom he helps to rule the kingdom.

The story seems to be a reworking of the Ovidian narrative of "Iphis and lanthe" (Ovid IX.666797; see Durling). Its later versions include a dramatic adaptation of the story of Yde entitled Miracle de la fille d'un roy, ${ }^{\text {iv }}$ one of the Miracles de Notre Dame par personnages, a collection of forty confraternity plays from fourteenth-century Paris; a French prose text, written in 1454 -- that is, in the midst of the rehabilitation of that most famous of medieval women cross-dressers, Joan of Arc (Weever 389) -- for three nobles at the court of Charles VII, and printed in the early sixteenth century as part of Les prouesses et faictz merveilleux du noble huon de bordeaulx (ff.166v-178r); ${ }^{\vee}$ and the very close English prose translation of Les prouesses by Sir John Bourchier, Lord Berners, apparently produced for Frances Hastings, second Earl of Huntingdon. The English text was published as The Boke of Duke Huon of Burdeux sometime in the first half of the sixteenth century, reprinted c.1570 and again, with minor editorial changes in $1601 .^{\text {vi }}$ 
Within a work like Yde et Olive, which is part of an epic cycle, a genre structured around genealogy (Bloch 92-127; 93), incest can simultaneously initiate and threaten to disrupt the action of the narrative (Durling 257). According to Claude Lévi-Strauss, the incest taboo is fundamental to the traffic in women which controls the patriarchal economic and social order. The prohibition of incest is a critical aspect of the paternal role--if the father were to defy this prohibition, the entire structure of society would be undermined. Yde et Olive includes an explicit discussion of Christian teaching on marriage and of the late medieval consanguinity laws. When Florent announces his intention to marry his own daughter to his assembled councilors, he is warned:

Gardons la loi que il nous commanda

Cis iert honnis qui le trespassera

Le mariage quant il le commanda

Tous crestïens Jesucris commanda

Ca son parage ne se mariast pas

Tu ne le pues avoir dusques en qart

$\mathrm{U}$ autrement bougrenie sera

[Let us heed the law that He commanded unto us:

He who trespasses against it will be damned.

When He ordained marriage,

Jesus Christ ordered every Christian

Not to marry his kin;

You cannot take kin to within the fourth degree

Otherwise it will be buggery.]

(YO 6445-51) vii

This admonition conforms to the official definition of incest put forward by the Fourth Lateran Council of 1215 which forbade marriage to one's mother or father, brother or sister, uncle or aunt, first or second cousin. Incest in the first degree, in other words between a parent and its child, rendered it impossible for the child to give to the parent due respect, and was regarded as unnatural and particularly abhorrent. As George Duby's work on marriage has revealed, the Church decrees on incest, as with its other edicts on matters relating to sexuality, cannot be separated from issues of social and political expediency and the clergy and the aristocracy often found themselves at odds with one another (The Knight, the Lady, and the Priest and Medieval Marriage). Florent's desire to marry one of his own kin was hardly unique and father-daughter incest is a fairly common motif in medieval French literature (see Gradval and McLaughlin). Whether or not one agrees with Jack Goody's view that the Church's ban on incest changed the ideology of marriage in the Middle Ages, the preservation of lineage remained a primary concern of the late medieval feudal aristocracy (102). ${ }^{\text {vii }}$ The Thomist justification for the incest prohibition stressed that one of the main advantages of exogamy was that it reinforced ties between different groups in society (Aquinas 154.9). Incest, it was argued, would both disrupt the household and weaken ties within the community. Alliances between powerful and wealthy families were to be encouraged. Florent's decision to marry his own daughter against her will also offends against another aspect of church teaching: from the mid-twelfth century on, the canonists insisted that the consent of each of the partners, and not simply that of the families, was crucial if the contract was to be binding (Brooke 128-33, Brundage 236-8, Duby 17, Herlihy 8082). ${ }^{\text {ix }}$

Endogamous marriage is then represented in Yde et Olive as unacceptable. One of the underlying anxieties in the text relates to the question of who will be Florent's heir. While the text does offer a psychological explanation for Florent's incestuous desire (he suffers tremedous grief at the loss of his wife, and as she grows up Yde increasingly reminds him of her), in marrying his own daughter, it would seem that Florent wants, quite literally, to keep his kingdom in the family. This is something he will otherwise be unable to do since, according to the principles of patrilineage and in the expected order of things, it should pass into the possession of the family into which Yde marries. Nonetheless it is extremely doubtful that the offspring of such an illegitimate union between father and daughter would legitimately be able to inherit the kingdom. Whereas in La fille d'un roy it is the vassals themselves who first propose that their king should marry Ysabel, in Yde et Olive the response of Sorbarrés, Florent's chief advisor, to his monarch's plan is one of incredulity and horror: he tells the King of Aragon that he will be damned in Hell if he carries it out (YO 6363-4). Meanwhile the lords and general populace fear such a marriage will bring about widespread destruction of the realm: 
Dont tante dame iert encor esplourée

\& tante terre \& destruite \& gastée

Tante jovente en iert deshyretée

Tante pucelle orphenine clamée.

[God, why does the king have such a thought

That will leave so many ladies soaked in tears

And so many lands destroyed and laid waste?

So many young people will be disinherited through it,

So many maidens declared orphans.]

(YO 6379-83)

While both the French prose version and the English translation include similar warnings, it is only in Yde et Olive that the anticipated disaster occurs and Florent is punished for his incestuous desires: in the continuation of the narrative, La chanson de Croissant, in the section attributed by Max Schweigel, the nineteenth-century editor of the text, to a second poet (32), it is said that Florent died of grief after Yde's departure and Aragon is only restored to Yde by his maternal grandfather, Huon of Bordeaux.

In Yde et Olive, Les prouesses and Huon of Burdeux, the incestuous union of the King of Aragon and his daughter is juxtaposed to the father-daughter relationship of the Emperor and Olive, with parallels between the two plots serving to highlight the differences between the relationships. The Emperor, like Florent, lacks a male heir and at first it appears that Oton's feelings for his (apparently motherless) daughter may not be any more innocent than those of Florent. Just as we are told that Florent turned away Yde's many powerful suitors because he wanted to keep her for his own company, so, it transpires, Oton has refused to give Olive in marriage to the King of Spain. The dangers of failing to maintain the exogamous marriage system are reiterated. Exactly the sort of national disaster which Florent's people had anticipated has befallen the Empire--the country has been invaded and the Spanish King intends to kill Oton and rape his daughter. In the opinion of the messenger who brings Oton news of the invasion, it would have been better if Olive had been married off and all this trouble had been avoided. Nonetheless, the fact that the anticipated destruction of the country does not occur indicates that the father-daughter relationship is not culpable, after all, in this case. If the relationship between Florent and Yde is explicitly condemned, that between Oton and Olive is represented as normative.

Florent's proposed marriage to his daughter is also paralleled in the union of Yde and Olive, and again this is signaled by repeated plot motifs and linguistic echoes. Indeed, the use of the word bougrenie to describe Florent's incestuous desire for his daughter in Yde et Olive is particularly suggestive because it anticipates the marriage between the two women which will prove to be the central crisis of the narrative. The French word bo(u)gres means "Bulgars" or "heretics" and refers to the Albigensians, whose heterodox beliefs were thought to have spread from Bulgaria; it was widely believed that the Albigensians actively encouraged homosexual sex (an accusation that was also made against many other heretical sects). ${ }^{x}$ The application of the term bougrenie to a breach of the laws of consanguinity could simply imply, as Nancy Vine Durling contends, that such a transgression is contrary to both Church teaching and the laws of nature (258). Certainly the French prose version of the tale, which does not refer explicitly to the legal ordinances but dwells instead on Yde's innocence and the extent to which the king's behavior is a corruption of normal paternal behavior, uses the word slightly differently, but the connotations are similar. Sorbarre declares that the match is unacceptable "car pis vauldroit que bougrerye que a celluy qui de ton sang propre as engendre vouldroys ainsi pollir" [ "because it would be worse than buggery to want to corrupt thus one's own begotten kin"] (PFM f.167r col.2) translated in Huon of Burdeux as "it is worse then bogery to hym that wyll polute his owne proper blode by hymselfe engendered" (HB 693-4). ${ }^{\text {xi }}$ Recent scholarship (Conner 129) has, however, challenged the view expressed by Michel Foucault and reiterated by Jonathan Goldberg and others that terms like "buggery" and "sodomy" (and their French equivalents) represent "utterly confused categor[ies]" which could include not only heresy, but also heterosexual anal intercourse and bestiality as well as homosexual acts. Studies of French sources reveal that the ambiguity of these words has been exaggerated, that their specific meanings--although multiple--were usually delimited by context. Later on in the French prose text (but not in Yde et Olive) boguerye is employed again, but in a much more specific sense, in the Emperor's horrified response to the discovery that he has married his daughter to a woman: "car pour riens ne vouldroit souffrir telle boguerye" ["because under no circumstances would he suffer such buggery"] (PFM f.175r col.1). In the English text we are told "he wolde not suffre suche boggery to be used" (HB 727). it is clear that boguerye or "boggery" is being applied to homosexual acts between women. Taken 
together, these examples indicate a conceptual link between female homosexuality and incest, further evidence of which can be found both in the Ovidian source and in the narratives themselves (see also Brooten 131n.57).

In Ovid's Metamorphoses, the story of Iphis and lanthe follows that of Byblis who lusted after her brother Caunus, and the thematic link between the two narratives is explicitly stated: "Fami novi centum Creteas forsitan urbes implesset monstri, si non miracula nuper / Iphide mutata Crete propiora tulisset" ["The story of this unnatural passion would, perhaps, have been the talk of Crete's hundred towns, if Crete had not lately had a wonder of its own in the changed form of Iphis"] (IX.6668). Although the suggestion is that it is Iphis's transformation into a man which is "unnatural," Iphis herself laments that her desire for another woman is unlawful and contrary to the decrees of nature (Ovid IX.726-63). ${ }^{\text {xii }}$ Not even female animals, she claims, love other females. Both incest and lesbianism are then described here as unnatural forms of sexual intercourse. ${ }^{\text {xiv }}$ Furthermore, both incest and lesbianism might also be conceived of as forms of narcissism, in which the object of desire is a fantasy projection of oneself. Georgiana Donavin describes incest as "the narcissistic sexual pursuit" (50), and the connection is illustrated in Ovid's story of Byblis--Caunus is in fact her twin. That lesbian desire is another example of like desiring like is also suggested by the Ovidian source of Yde et Olive, which stresses the similarity of Iphis and lanthe who are the same age and equally beautiful (IX.718-19).

In Yde et Olive, Les Prouesses and Huon of Burdeux, incest and female homosexuality challenge the prohibitions of patriarchy which seek to contain sexuality and control women. Both therefore threaten to destabilize the structures of society. According to Elizabeth Archibald, "At first [Yde's] virtue and her happiness are threatened by inappropriate endogamy ... but at the end the crisis is caused by inappropriate exogamy, the emperor's perfectly reasonable attempt to marry his daughter to his new champion, which unknown to him threatens to be a union just as sterile and dangerous for his lineage as incest." (Archibald 9) In the metrical text, Yde's realization that she must go through with the marriage to the Emperor's daughter is followed by an interior monologue which emphasizes the link between her current predicament and her past one. In an apostrophe to Florent she says:

Mix me laissasse en un fu embraser

Je menfuï pour la honte eskiver

De ton païs par ton pecié mortel

En maint peril a puis mes cors esté

[Better to have let myself burn in a fire!

To avoid disgrace I fled

From your country. Because of your mortal $\sin ^{x v}$

I have since been in many dangers.]

and she continues: (YO 7074-77)

Or me cuidai dedens Romme garder

Mais jou voi bien mes cors ert encusés

La fille au roi a mon cors enamé

Or ne sai jou comment puisse escaper

Se jou lor di femme sui par verté

Tantost maront ochis \& decopé

U a mon pere diront la verité

[Then I thought I could stay safely hidden in Rome,

But I see well that I am revealed.

The King's daughter has fallen in love with me;

Now I do not know how I can escape.

If I tell them I am really a woman,

They will kill me and cut me up immediately,

Or they will tell my father the truth.]

(YO 7078-84)

In other words, having escaped Florent's perverse lust, Yde is trapped by a potentially more dangerous female desire, and the two forms of desire are inextricably linked. As Durling notes, continuing dread of Florent governs Yde's response to the new situation (261).

It is somewhat surprising, therefore, that in Yde et Olive and the French and English prose texts, the same-sex marriage of Yde and Olive is represented in more positive terms than the incestuous union of Yde and her father. Olive's feelings towards her husband are unambiguously sexual--when she first looks at the warrior she trembles with joy ( $\underline{\text { YO }} 6988)$. Her desire is stimulated 
not only by her squire's performance on the battlefield and in the court but also by Yde's physical appearance. In bed Yde pretends to be ill, but Olive, who seems to have an inkling of what is going on, reassures her husband that they are well hidden and that she desires nothing more than to be with him. ${ }^{\text {xi }}$ But after Olive proves too insistent in her demands, Yde is forced to confess all. Olive's response is not one of disgust at being deceived and thus tricked into bed with a woman, but one of horror when her lover tells her about Florent's intentions. In Les prouesses Olive addresses Yde intimately at this point as "ma tresdoulce amye" ["my very sweet beloved"] (PMF ff.174v col.2-175r col.1), translated in the English text as "my right swete lover" (HB 726).

Yet if Olive's response is one of compassion when she understands the plight of her lover, the reaction of the general populace to the news that Oton has given his daughter and country to a woman is an even greater outcry than that which greeted Florent's announcement that he would wed his daughter: both women must be executed. ${ }^{\text {xvii }}$ Although, homosexuality in general, and lesbianism in particular, like incest, can be seen to disrupt the patriarchal social order by by-passing the institution of marriage and defying compulsory heterosexuality, the reason for this extreme reaction is not simply moral outrage but also, once again, fear about the consequences for the realm of an unnatural union. It is one thing to marry a princess to a pauper (who, nonetheless, claims to have worthy kindred), and quite another to marry her to a woman. Inheritance is, yet again, a crucial issue, because two women together cannot provide the Emperor with an heir.

If the narrator makes no moral judgments about the pre-marital relationship between the two women, the explanation for his stance may be that the disruptive potential of female same-sex desire is dissipated as the narrative progresses. ${ }^{\text {xviii }}$ While they may still be voyeuristically observed, the women's embraces are merely a precursor to normative heterosexual relations and are not seen to threaten the dominance of the heterosexual model. In the long term, they do not signify and, in so far as they are insignificant, they remain invisible. At the crisis point of the narrative, the moment when the relationship between the women does becomes fleetingly visible and when the Emperor discovers Yde to be a woman, she is transformed into a man. The homophobic response of the court is the catalyst which brings about Yde's sex change. It is only then that the homoerotic elements of the text have to be repressed and the charge of female homosexuality is fully repudiated. ${ }^{\text {xix }}$ The resolution of the crisis surrounding the marriage of the two women signals a return to the normative structures of heterosexual marriage and childbirth. Olive's pregnancy signals the resumption of sociallyrecognized sexual relations--reproduction renders their unnatural passion "natural" (Brundage 580 and Boswell, Christianity 164-5). Furthermore, the alliance of the progeny of the Aragon monarch and the Roman Emperor proves all the more politically advantageous once the true identity of the former is known and he is able to inherit both kingdoms. The narrative resolution provides not just Oton but also Florent with a direct male descendant and thus enables the transmission of both their property according to the rules of patrilineage.

"Hardye batailleresse" or "bon chevalier"? the querying of masculinity

At the same time as Yde et Olive forces the reader to think about questions of sexuality, it also interrogates assumptions about and perceptions of sex and gender and constructions of masculinity and femininity. We might question whether, in this text, biological sex is privileged over socially-constructed gender; whether sex is, in any sense, represented as more real than gender? $?^{x x}$ Recent studies of medieval and renaissance literature have emphasized the transgressive potential of female transvestitism: putting on men's clothing was sometimes more than a temporary measure taken to enable flight or the pursuit of a quest, it could also signal complete rupture with the past (Perret 329; see also Dollimore, Epstein and Straub, Garber, Bullough and Bullough, and Hotchkiss). Valerie Traub argues that women who cross-dress do not simply imitate or take the part of the man, but (using Jonathan Dollimore's terminology) she suggests that they transgressively reinscribe gender by deconstructing the notion of "man," revealing the "original" to be itself an "image" (155). As Simon Gaunt puts it (following Marjorie Garber and Judith Butler), "cross-dressing is often a symptom of cultural anxiety, not so much a crisis of and in gender categories, but a crisis of category itself." ("Straight Minds" 165) I would argue that in Yde et Olive, as in the later versions of the tale, with the exception of the play, the distinction between sex and gender is an unstable one. It is never entirely clear to what extent Yde's masculine and feminine qualities are either "natural" or performed. The perspective is constantly shifting.

Yde's gender-bending may be explained to some extent by nurture, specifically by the death of her mother (and thus the absence of a primary bond crucial to gender identification), but her biological identity is not brought into question at the beginning of the text. In the Middle Ages education was crucial to the gendered and class-based socialization process (see Shahar). The text 
highlights stages in Yde's maturation by repeatedly drawing attention to her age in a manner which is far from arbitrary. Unlike Iphis, who is brought up from birth as a boy, ${ }^{x \times i}$ in the first years of her life Yde is educated in a way which would be appropriate to aristocratic children of either sex. At the age of seven (the age when the education of noble boys and girls separated), she is instructed in letters, and can read her Psalter, and write Latin and the vernacular Shahar 209-24; 220). At fourteen, the age of maturity for boys--the minimum age of marriage for girls was twelve (Shahar 28 and 224)--the King opposes her marriage to other suitors and when she is just a year older, he decides to marry her himself. Florent's fifteen-year-old daughter is represented as a stereotypically beautiful woman. Dressed in finery for the marriage, her physical beauty is described in what are on the whole highly conventionalized terms--her white and red complexion, sparkling eyes, golden blonde ringlets, perfect features, delicate hands, slender hips (YO 6465-83). The narrator, who here adopts a voyeuristically masculine stance, draws our attention to her lack of maturity, both by his use of diminutives and by noting that her breasts have not yet developed, as far as can be seen (YO 6483). Yet as Jacqueline de Weever notes, there are androgynous elements in this portrait: men rather than women are usually given curly hair, and Yde's small breasts will later expedite her disguise (375). The overlap between ideals of masculine and feminine beauty facilitates the gender confusion which follows (Hotchkiss 119-23), but the implication is that Yde can only masquerade as a young man before she enters into full womanhood, a reversal of the usual association of effeminacy with male youth (c.f. Gilbert 42-3).

If in her earliest years, Yde's feminine accomplishments and physical beauty correspond to her sex, when she puts on male clothing her outward appearance appears to be privileged over biology. Whereas, in all the other versions of the narrative, the initiative behind the disguise comes from her helpers (in Les prouesses and Huon of Burdeux, it is Sorbarre and the governess who come up with the plan and provide the clothing; in La fille d'un roy, Ysabel is accompanied in her flight by a female servant, also disguised as man, as well as a male retainer and the angel Gabriel), in the chanson Yde is operating on her own. When she decides to dress as a boy, putting on boots, a hood, belt and breeches, and rides out on her father's "destrier" or "war-horse", it is clearly to assist her escape, but, I would argue that even before her miraculous sex change, Yde appears to have undergone not merely a superficial, but a psychological and physical transformation. Our attention is drawn to this by the recurring motif of the test which Oton constructs to discover the "truth" about Yde's biological sex (Durling 259-60 and Weever 382). This symbolic rebirth, with its connotations of baptism, ${ }^{x x i i}$ echoes a much earlier occasion when Yde bathed in preparation for her marriage to her father immediately before she underwent her first sexual transformation. ${ }^{\text {xiii }}$ Yde's sex change has already been anticipated in the narrative by her cross-dressing: by putting on a man's clothing, Yde seems actually to become a man in every way but one--not only her appearance, but her values, attributes and body metamorphose. All she lacks is the male organ, although the fact that Yde carries a staff and a sword (YO 6551) is crudely suggestive of her new-found virility, the sword and staff being equated with the phallus, which is, according to Lacan--following and revising Freud--the privileged signifier of gender (Mitchell and Rose 6-7).

Weever observes that exile from the mother country and setting out on a quest represents "one of the stronger motifs in the formation of the heroic character." (378) She also explains that after fleeing Aragon, Yde undergoes a second education, and this time it is one which is appropriate to a male youth: she experiences an apprenticeship as a squire, wins her spurs and becomes a knight, and is promoted to the rank of general (373). The episodes which describe her adventures after renaming herself--she declares "Jai non Ydés" ["My name is Ydés"] (YO 6585) ${ }^{\text {xii }}$--and after entering the service of a mercenary leader are concerned with the stages in Yde's maturation as an epic or romance hero. Yde is as convincing and successful as a young man as she was as courtly maiden. In the two skirmishes with ambushers and robbers which follow, Yde knows instinctively what to do in battle, outfighting all the men and demonstrating an apparently instinctive courtoisie and courage. To some extent this may be explained by her noble background--aristocratic lineage and good breeding might be seen to outweigh sex and gender. ${ }^{\times \times V}$ In the French prose text and the English translation Yde/lde demonstrates compassion in interceding before the Emperor for the life of the captive Spanish king (PFM 173r col.2; $\underline{\mathrm{HB}}$ 719), which could be seen as either a feminine trait or a noble attribute. If to curse one's foe with the words "fil a putain" ["son of a bitch"] (YO 6756) is to use what Weever considers to be "most unladylike speech" (378), it is also a standard insult, perfectly in keeping with warrior custom and this may be taken as an example of Yde playing the part she has taken upon herself. But birth, upbringing and role-playing do not fully explain such a whole-hearted adoption of the knightly role: physical strength as well as cunning is necessary for Yde to overcome the leader of the robbers in a wrestling match.

Even if Yde's appearance and physical strength belie her "essential" femaleness and her success in combat belies her femininity, by referring to her as la damoiselle, la pucelle, la bele, la bele 
o le cors gent, and so on, the narrator never allows the reader to forget that Yde is still a woman, at least in his eyes. A similar effect is created in the French prose text: Yde is even designated "hardye batailleresse" ["a daring and pugnacious woman"] (PFM 170v col.1). Marjorie Garber cautions us against looking through the transvestite rather than at her/him (9). It could be argued that the narrator of the chanson falls into this trap and attempts to close down the subversive potential of Yde's new identity as neither male nor female but both. For example, when the bathing test is set up after Yde's secret has been made known to Oton, the narrator mirrors her literal and metaphorical exposure by describing her as "au cors mollé" ["with the shapely-body"] (으 7210) and thus draws attention to her now unveiled female form. ${ }^{\text {xxi }}$

If no inflexible opposition between Yde's feminine and masculine roles is sustained through the gendering of the name in Yde et Olive, the same can be said of other forms of grammatical gender. Sometimes the use of feminine and masculine pronouns and grammatical endings changes simply depending on whether we are given direct or indirect speech or reported action; occasionally it seems to be influenced by formal requirements (the constraints of meter and rhyme). Nevertheless linguistic indeterminacy is also used deliberately to convey different ways of seeing. ${ }^{\text {xvii }}$ Thus, in the account of his first encounter with the knight, Oton's point of view is reflected in the physical description we receive of Yde--Oton is impressed, not only by Yde's courteous speech but also because he is "grant et membru et formé" ["big and sturdy and well-built"] (YO 6807). In this passage grammatically masculine pronouns are used, and we might compare it to the narrator's description of Yde a short time later, in which her impressive physical appearance--her height, strength and build--is again praised, but grammatically gendered feminine (YO 6885). ${ }^{x v i i i}$ The distinction between Yde's sex and gender is blurred. The idea that Yde is simply disguising her sexual identity is brought into question by the attribution to her of what are usually seen to be biologically masculine characteristics. The point seems to be that sex as well as gender difference is, at least to some extent, a matter of perception. Yde's reiterated performance produces a body which is at times (but only at times) culturally intelligible as male. .xix

At various key moments in the narrative Yde herself, like the narrator, is all too aware that she is a woman beneath her clothing. For example, at the time of the Spanish invasion, she prays to God for protection because she is fully aware of her vulnerability, even if she has been changed into a man (YO 6958). When Yde is fighting with the thieves, she says to herself "Bien doi avoir prouece \& hardement / Quant je sui fille au rice roi Florent" ["I really must be brave and valiant, / Being the daughter of the noble King Florent"] (YO 6762-3). But even here it is far from clear that she is undergoing anything approaching a crisis over her gendered identity. Rather than expressing despair at being the daughter, not son, of Florent, she is seeking inspiration by reminding herself of her own noble birth. The qualities she evokes are those of chivalric perfection, the vocabulary is that of the epic (Weever 379). It is only when Yde realizes she must wed Olive that she experiences any heartfelt despondency, lamenting her own falsehood in her pursuit of Rome and honor (YO 7089). And even as she acknowledges she has sinned by harboring masculine ambitions--marriage and inheritance are after all the objectives of the epic quest (Weever 381) and of romance--she resolves to trust in Providence and go along with Oton's plans.

Sexual activity is a crucial indication of male maturity and also of chivalric identity (see Gilbert 43 and Hotchkiss 118). It is no chance that the most important occasion in which Yde's femininity reasserts itself is after her marriage to Olive. Valerie Hotchkiss contends that at this stage Yde's sexual orientation is "vaguely defined and in the early stages of development" (115) but such a reading is over-simplistic. Yde does not conform to the image of the chaste woman warrior encountered elsewhere in medieval and renaissance romances (see Weever 380 and Watt 168-9). Yde's response to Olive is not outright rejection, but one of confusion--her blood is in turmoil (YO 7064). Yet, there is no monologue on the subject of unnatural passions to correspond to Iphis's heartfelt lament in the Ovidian source. Rather Yde's principal concern is that the marriage will not be consummated--that she cannot, at this point, behave like a man. ${ }^{\mathrm{xx}}$ The narrator comments that Yde "Ne set comment se porra demener / Na membre nul qua li puist abiter" ["She does not know how she should behave; she has no member with which she can touch her"] (YY $7065-6$ ). used to describe the (unconsummated) love-making of the two women are those of battle: "Dont ont lun lautre baisie \& accollée / En cele nuit ni ot cri ne mellée" ["Then they both kissed and embraced each other; / That night there were no war cries or skirmishes"] (YO 7152-3). ${ }^{x x x i i}$ The knight's love service mirrors her service to the Emperor and, despite Yde's own avowals to the contrary (her claim that she lacks a "membre"/"member"), it is not unfeasible that she should succeed in the bedroom as well as on the battlefield. The language the narrator uses to describe Yde's procrastination may even suggest that she could have used a prosthetic supplement had she so wished: "Et Yde jut avoecques sespousée / Ne la nient plus que soloit aparlée / Devers les rains pointe ne adesée" ["And Yde lay 
with her/his wife, / S/he didn't speak to her any more than usual; / Or jab or touch her in her nether regions"] (YO 7167-69). The language here is implicitly sexual. ${ }^{\text {.xxiii }}$ Similarly, in the French prose version, the narrator records that Yde lay with her wife for fifteen nights but "elle ne approchoit ne tastoit excepte de baiser \& accoller" (PFM f.174v col.2) ["she did not approach or touch her except with kissing and embracing"]. Although the pairing of acoler and baisier can suggest some degree of sexual communion, ${ }^{x x x i v}$ the key word here is the verb taster, which, in Old French, can mean "taste" or "enjoy" as well as "touch", connotations of oral or penetrative sex which are lost in the translation, which simply has it that "yde touched her not but with clippyng and kyssyng" (HB 725). ${ }^{x \times x v}$ Even if the narrator denies that it has taken place, the possibility of intercourse is certainly raised. The absence of a penis, does not, in principle, stop her from playing the male role in intercourse ${ }^{x \times x v i}$ and it comes as no surprise that she should become the focus of masculine dread. $x$ xxvii

Weever argues that in the chanson, grammatical gender stabilizes from the moment of the angel's intervention (388). Certainly in the dramatic adaptation Ysabel's transformation is only temporary ${ }^{x \times x v i i i}$--the play ends with her marrying the Byzantine Emperor and her father marrying the Emperor's daughter--and serves to confirm the split between gender and sex; the former may be fluid but the latter is fixed. However, in the other versions of the narrative, the sex-transformation does little to clarify the gender-confusion that occurred earlier in the texts. In the chanson, for example, the angel who appears before Oton simply declares that Yde is a now a "bon chevalier" [ a "good knight"] (YO 7229): "Hui main iert feme or est uns hom carnés" ["This morning s/he was a woman, but is now a man by magic"] (YO 7234). The real difference is that with the angel's prophecy of the birth of Croissant (in Les prouesses and Huon of Burdeux Croissant is conceived that very night), Yde is granted a potency she formerly may have lacked. Unlike Ovid's tale of Iphis and lanthe, which dwells on the metamorphosis of the former as her strides lengthen, her complexion, features and hair change, and her body strengthens and becomes more vigorous (IX.786-90), there is no description in the chanson, Les prouesses or Huon of Burdeux of Yde's/lde's transformed physical appearance. No doubt this is because none is necessary since, as I have already argued, these transformations were anticipated at a much earlier stage.

\section{Conclusion}

It may be significant that this is only an episode in a larger cycle, a flight of fancy which transpires to be incidental both to the continuity of Huon of Bordeaux's line of succession and thus to the whole epic cycle when, at the end of La chanson de Croissant, Ydés' maternal grandmother Esclarmonde, blessed with the gift of eternal youth, finally provides Huon with a direct male successor. In this flight of fancy, love between two women is sympathetically contrasted with the unacceptable incestuous desire of a father for his daughter, and the woman who behaves like a man is represented positively as a worthy hero. To return to my starting point, it would be moot to describe either Yde or Olive as lesbian if, as Brooten suggests, sexual orientation is integral to our definition of that term. It is also apparent that the transvestite/transsexual occupies, at least to some extent, the conceptual space of the lesbian, rendering the latter term all the more problematic in this instance. Nevertheless, the thesis that the transgression of gender roles is central to the condemnation of sexual relations between women is borne out by the various versions of this story. In Yde et Olive, Les Prouesses and Huon of Burdeux, it is neither Olive's longing nor even Yde's cross-dressing which is condemned. Instead, just as both the lack of male heirs for Florent and Oton and the former's incestuous plans threaten the established social order, so too does the women's marriage. What we might now think of as lesbian desire cannot be tolerated if it threatens to disrupt the laws of patrilineage. Furthermore, even if, in depicting a woman succeeding as a knight, the narrative challenges feudal ideology by undermining its underlying assumption that only men are capable of carrying out their chivalric duties, such a message is counter-balanced by an inherent caution or conservatism. Ultimately the woman who succeeds too well in passing as male has no choice but to reassert her femininity (as does Ysabel in the dramatic text) or to transform into a man (as does Yde/lde in the other versions). The moral would seem to be twofold: noble virtues are innate qualities and aristocratic birth will out, and the woman who behaves like a man might just become one.

University of Wales, Aberyswyth 
Works Cited

Aquinas, Thomas. Temperance (2a2ae. 141-54). Ed. and trans. Thomas Gilby. London: Blackfriars, 1968. Vol. 43 of Summa Theologiae. 60 vols. 19641976.

Archibald, Elizabeth. "The Ide and Olive Episode in Lord Berners's $\underline{\text { Huon of }}$ Burdeux." [forthcoming].

Bailey, Derrick Sherwin. Homosexuality and the Western Christian Tradition. London: Longmans, Green and Co., 1955.

Blake, N.F. "Lord Berners: A Survey." Medievalia et Humanistica ns 2 (1971): 119-

Bloch, R. Howard. Etymologies and Genealogies: A Literary Anthropology of the French Middle Ages. Chicago: University of Chicago Press, 1983.

Boswell, John. Christianity, Social Tolerance, and Homosexuality: Gay People in Western Europe from the Beginning of the Christian Era to the Fourteenth Century. Chicago: University of Chicago Press, 1980.

---. "Revolutions, Universals, and Sexual Categories." Hidden From History: Reclaiming the Gay and Lesbian Past. Ed. Martin Duberman, Martha Chauncey, Jr. London: Penguin, 1991.17-36.

Bourchier, John, trans. The Boke of Duke Huon of Burdeux. Introduction. S.L. Lee. 4 parts. Early English Text Society, Early Series 40, 41, 43, 50. London: Trubner, 1882-1887.

Brooke, Christopher N.L. The Medieval Idea of Marriage. Oxford: Clarendon, 1994.

Brooten, Bernadette J. Love Between Women: Early Christian Responses to Female Homoeroticism. Chicago: University of Chicago Press, 1996.

Brundage, James A. Law, Sex, and Christian Society in Medieval Europe. Chicago: University of Chicago Press, 1987.

Bullough, Vern L., and Bonnie Bullough. Cross Dressing, Sex, and Gender. Philadelphia: University of Pennsylvania Press, 1993.

Butler, Judith. Bodies that Matter: On the Discursive Limits of "Sex". London: Routledge, 1993.

---. Gender Trouble: Feminism and the Subversion of Identity. London: Routledge, 1990.

Cadden, Joan. "Sciences/Silences: The Natures and Languages of 'Sodomy' in Peter of Abano's Problemata Commentary." Lochrie, McCracken and Schultz 4057.

Camille, Michael. "Manuscript Illumination and the Art of Copulation." Lochrie, McCracken and Schultz 58-90

La chanson de Croissant. Schweigel 162-73.

La chanson d'Yde et Oliue. Schweigel 152-62.

Conner, Randy P. "Les Molles et les chausses: Mapping the Isle of Hermaphrodites in

Premodern

France." Livia and Hall 127-46.

Cornuälle, Heldris de. Le Roman de Silence. Trans. Regina Psaki. New York: Garland, 1991.

---. Silence: A Thirteenth-Century French Romance. Ed. and trans. Sarah RocheMahdi. East Lansing: Colleagues Press, 1992.

Daston, Lorraine, and Katharine Park. "The Hermaphrodite and the Orders of Nature:

Ambiguity in Early Modern France." Fradenburg and Freccero 117-36.

DeJean, Joan. Fictions of Sappho, 1546-1937. Chicago: University of Chicago Press, 1989.

Dollimore, Jonathan. Sexual Dissidence: Augustine to Wilde, Freud to Foucault. Oxford: Clarendon Press, 1991.

Donavin, Georgiana. Incest Narratives and the Structure of Gower's Confessio Amantis. ELS

Monograph Series 56. Victoria, BC: n.p., 1993.

Duby, George. The Knight, the Lady, and the Priest: The Making of Modern Marriage in Medieval France. Trans. Barbara Bray. Intro. Natalie Zemon Davies. London: Penguin, 1985.

---. Medieval Marriage: Two Models from Twelfth-Century France. Trans. Elborg Foster. Baltimore: John Hopkins University Press, 1991.

Durling, Nancy Vine. "Rewriting Gender: Yde et Olive and Ovidian Myth." Romance Languages Annual 1 (1989): 256-62.

Epstein, Julia, and Kristina Straub, eds. Body Guards: The Cultural Politics of Gender 
Ambiguity. London: Routledge, 1991.

Foucault, Michel. The History of Sexuality, Vol. 1: An Introduction. Trans. R.

Hurley. London: Allen Lane, 1979.

Fradenburg, Louise and Carla Freccero. Premodern Sexualities. London: Routledge, 1996.

Garber, Marjorie. Vested Interests: Cross-Dressing and Cultural Anxiety. London: Penguin, 1992.

Gaunt, Simon. Gender and Genre in Medieval French Literature. Cambridge: Cambridge University Press, 1995.

---. "The Significance of Silence." Paragraph 13 (1990): 202-16.

---. "Straight Minds/ 'Queer' Wishes in Old French Hagiography: La Vie de Sainte

" Fradenburg and Freccero 155-73.

Gilbert, Jane. "Boys will be ... What? Gender, Sexuality, and Childhood in Floire et Blancheflor and Floris et Lyriope." Exemplaria 9 (1997): 39-61.

Godefroy, Frédéric, ed. Dictionnaire de l'ancienne langue française. 10 vols. Paris: Vieweg, 1880-1902.

Goodich, Michael. "Sodomy in Medieval Secular Law." Journal of Homosexuality 1 (1976): 295-302.

Goody, Jack. The Development of the Family and Marriage in Europe. Cambridge: Cambridge University Press, 1983.

Gradval, Kathryn. "Confessing Incests: Legal Erasures and Literary Celebrations in Medieval France." Comparative Literarature Studies 32 (1995): 280-295.

Greimas, A.J., ed. Dictionnaire de l'ancien français jusqu'au milieu de XIVe siècle. Paris: Librairie Larousse, 1969.

Herlihy, David. Medieval Households. Cambridge MA: Harvard University Press, 1985.

Hotchkiss, Valerie R. Clothes Make the Man: Female Cross Dressing in Medieval Europe. New York: Garland, 1996.

Jordan, Michael. The Invention of Sodomy in Christian Theology. Chicago: Chicago University Press, 1997.

---. "Homosexuality, Luxuria, and Textual Abuse." Lochrie, McCracken and Schultz 24-39.

Kinoshita, Sharon. "Heldris de Cornuälle's Roman de Silence and the Feudal Politics of Lineage." PMLA 110 (1995): 397-409.

Lévi-Strauss, Claude. The Elementary Structures of Kinship (Les Structures élémentaires de la Parenté). Rev. ed. trans. James Harle Bell, John Richard von Sturmer and Rodney Needham. London: Eyre \& Spottiswoode, 1969.

Livia, Anna and Kira Hall, eds. Queerly Phrased: Language, Gender, and Sexuality. New York: Oxford University Press, 1997.

Lochrie, Karma, Peggy McCracken and James A. Schultz, Constructing Medieval Sexuality. Minneapolis: University of Minnesota Press, 1997.

McLaughlin, Megan. "'Abominable Mingling': Father-Daughter Incest and the Law." Medieval Feminist Newsletter 24 (Fall 1997): 26-30.

Middle English Dictionary. Ed. Hans Kurath and S. M Kuhn. 13 vols. and 5 parts to date. Ann Arbor: University of Michigan Press, 1956-.

Miracle de la fille d'un roy. Ed. Gaston Paris and Ulysse Robert. Paris: Librairie de Firmin Didot et Cie, 1883. Vol. 7, 1-117 of Miracles de Notre Dame par personnages. 8 vols. 1876-1893.

Mitchell, Juliet, and Jacqueline Rose, eds. Feminine Sexuality: Jacques Lacan and the école freudienne. London: Norton, 1985.

Mitterauer, Michael. "Christianity and Endogamy." Continuity and Change 6 (1991): 295-333.

Murray, Jacqueline. "Twice Marginal and Twice Invisible: Lesbians in the Middle Ages." Handbook of Medieval Sexuality. Ed. Vern. L. Bullough and James A. Brundage. New York: Garland, 1996. 191-222.

Ovid. Metamorphoses. Ed. and trans. Frank Justus Miller. 2 vols. Loeb Classical Library. Cambridge, Ma.: Harvard University Press, 1958.

Oxford English Dictionary. Ed. J.A. Simpson and E.S.C. Weiner. 2nd ed. 20 vols. Oxford: Oxford University Press, 1989.

Perret, Michèle. "Travesties et Transsexuelles: Yde, Silence, Grisandole, Blanchadine." Romance Notes 25 (1985): 328-40. 
Les prouesses et faictz merveilleux du noble huon de bordeaulx. Paris: Michel le Noir, 1513.

Rothwell, W. "Adding Insult to Injury: The English Who Curse in Borrowed French." The Origins and Development of Emigrant Languages: Proceedings from the Second Rasmus Rask Colloquium, Odense University, November 1994. Ed. Hans F. Nielsen and Lene Schøsler. Odense: Odense University Press, 1996. 41-50.

Schweigel, Max, ed. Esclarmonde, Clarisse et Florent, Yde et Olive: Drei Fortsetzungen der chanson von Huon de Bordeaux. Ausgaben und Abhandlungen aus dem Gebiete der romanischen Philologie 83. Marburg: N.G. Elwert, 1889.

Sedgwick, Eve Kosofsky. Between Men: English Literature and Male Homosocial Desire. New York: Columbia University Press, 1985.

Shahar, Shulamith. Childhood in the Middle Ages. Trans. Chaya Galai. London: Routledge, 1992.

Tobler, Adolf, and Erhard Lommatzsch, eds. Altfranzösisches Wörterbuch. 10 vols. and 4 parts to date. Berlin/Wiesbaden: Weidmannsche Buchhandlung/Franz Steiner Verlag, 1915-.

Traub, Valerie. "The (In)significance of 'Lesbian' Desire in Early Modern England." Erotic Politics: Desire on the Renaissance Stage. Ed. Susan Zimmerman. London: Routledge, 1992. 150-69.

Watt, Diane. "Read My Lips: Clippyng and Kyssyng in the Early Sixteenth Century." Livia and Hall 167-77.

Weever, Jacqueline de. "The Lady, the Knight, and the Lover: Androgeny and Integration in La Chanson d'Yde et Olive." Romanic Review 131 (1991): 371 91. 
Notes

I should like to thank Daron Burrows for providing translations and for his invaluable help and extremely constructive comments and suggestions, especially concerning etymologies and definitions, and matters of style, syntax and meter. Without his contribution, this paper would have remained unwritten. Katrin Rupp generously shared some of her ideas with me and drew my attention to a number of texts and studies of which I might otherwise have remained unaware. Paulina Kewes, Claire Jowitt and Sarah Prescott read earlier drafts of this paper and I am grateful to them for their advice. All errors, are, of course, my own.

i For the term "lesbian" see Brooten 4-5 and 337.

${ }^{\text {ii }}$ In making connections between attitudes to female same-sex desire in the early Christian and the modern periods, Brooten tends to elide the later Middle Ages. This can be seen, for example, in her discussion of Sappho of Lesbos $(18,23,29-41)$. As Brooten explains, references to Sappho can be found in the writings of Byzantine and Latin theologians. Yet, I would suggest that for much of the later medieval period, Sappho was not associated with female homoerotic desire nor used (as Brooten suggests she was by modern writers) "to define female deviancy" (18). See also DeJean.

${ }^{\text {iii }}$ Cited hereafter by line number as $\underline{Y O}$. Yde's adventures can be fruitfully compared to those of Silence, the cross-dressing heroine of another French chanson de geste: see Cornuälle, Le Roman de Silence and Silence: A Thirteenth-Century French Romance. All quotations and translations from Silence are from the latter edition, which is by Roche-Mahdi; citations are by line number.

${ }^{\text {iv }}$ Cited hereafter by line number as $\underline{F R}$. Although the motifs of incest, cross-dressing, marriage of women and sex-transformation remain, this text is primarily concerned with religion rather than heroism and genealogy and varies considerably from the other versions of the narrative.

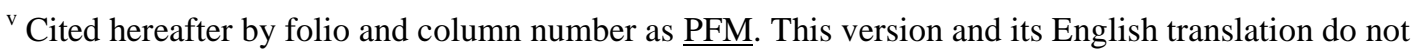
substantially deviate from the plot of the chanson until the end.

${ }^{\text {vi }}$ An edition was produced for the Early English Text Society by S.L.Lee in the nineteenth century. The Ide and Olive episode occurs in part 2,690-737. All quotations are from this edition, cited hereafter by page number as HB. The 1601 variants are included in the editorial apparatus. For the dating, see Blake. Recent studies include Archibald's forthcoming study and my own essay in Livia and Hall. I am grateful to Dr. Archibald for allowing me to read a copy of her article before its publication. 


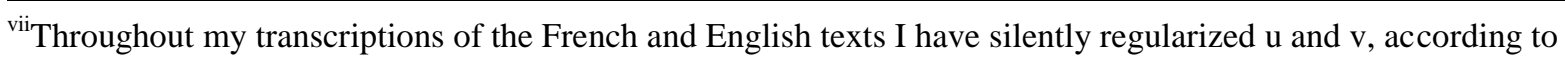
the conventions of modern orthography. All translations from Old and Middle French, unless otherwise stated, are by Daron Burrows.

viii Goody's views have been challenged by a number of scholars. For a survey of the different interpretations of the motivations and effects of the canon laws on incest, see Mitterauer 301-3.

On medieval marriage see also Brooke, Brundage, and Herlihy.

${ }^{\text {ix }}$ Recent studies have looked at the interaction of the shifts in marriage practices and the representation of marriage in vernacular texts. Simon Gaunt argues that the issue of consent is central to many romances ( $\underline{\text { Gender }}$ and Genre 120).

${ }^{\mathrm{x}}$ Tobler and Lommatzsch (cited hereafter as T-L) s.v. bougre, $\underline{\text { bougrerie, }}$ bougresie; Middle English Dictionary (cited hereafter as MED) s.v. bougre and bugerie; and Oxford English Dictionary (cited hereafter as OED) s.v.

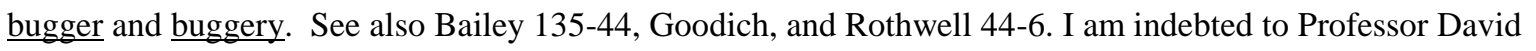
Trotter for drawing my attention to Rothwell's article. On the link between heresy and incest, see Goody 15860. On the meaning of sodomy, see also Jordan, "Homosexuality" and Invention, and Cadden.

"In the 1601 edition "bogery" is changed to "heathen" which would seem to indicate that the word was interpreted in its most general sense.

xii In the 1601 edition "boggery" is emended here to the more anodyne "falsehood".

xiii Archibald notes the contrast between this narrative and Ovid's account of Myrrha's incestuous relationship with her father (X.323-31), in which Myrrha is envious of animals because they are able to mate incestuously: Archibald n.11.

${ }^{\text {xiv }}$ On the normative as well as descriptive force of medieval notions of nature and what is natural, see for example, Daston and Park esp. 126. On incest as natural rather than unnatural, see Brooten 270n.11.

${ }^{\mathrm{xv}}$ The absence of punctuation renders ambiguous the interpretation of these lines. An alternative reading would be "I fled from you country because of your mortal sin."

${ }^{x v i}$ Silence also finds herself pursued by another woman, in this case the queen. Olive's response contrasts dramatically with that of the queen after her advances have been repulsed: "Certes, gel croi bien a erite / Quant a feme ne se delite / ... Herites est, gel sai de fi, / Et jo de m'amor le deffi” [“In fact, I'm sure he's a queer, / since a woman doesn't arouse him at all / ... He's a fag, I'd swear to it, / and my love threatens him”] (Conuälle, Silence 3935-6 and 3948-9). 
${ }^{\text {xvii }}$ On medieval punishments for same-sex intercourse between women, which included burning at the stake, see Weever 382 and Watt 171-2. See also Murray.

${ }^{\text {xviii }}$ C.F. Gilbert 45. Gilbert follows Sedgwick in arguing that what we would now think of as lesbian activities simply do not count in medieval culture. See also Sedgwick 1-20 esp. 2.

${ }^{x i x}$ On the dynamic relationship between homophobia and compulsory heterosexuality, see Foucault 3-49, Sedgwick 3-4, and Butler, Gender Trouble 57-72 esp. 64-5.

${ }^{x x}$ Here I am considering issues raised by Gilbert (53) in relation to Floire et Blancheflor and Floris et Lyriope.

${ }^{x x i}$ Like Iphis, Silence is also brought up as a boy. On nurture as a critical factor in Silence's gender identification, see Hotchkiss 118.

xxii As Durling notes (259-60), it was at Yde's baptism that Florent first heard the terrible news of his wife's death (O 6253-61).

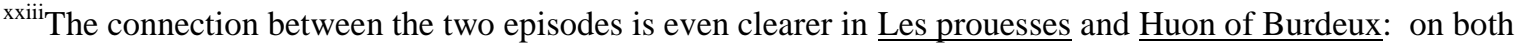
occasions, Yde/Ide tries to escape by claiming she isn't accustomed to bathing. Michelle Camille observes that, since one might be expected to bathe as preparation for sex, in medieval visual art bathing scenes can signify sexual desire (64-5).

${ }^{\text {xxiv }}$ However, in the manuscript, the name may not be accented (Weever 388). In the Old French metrical text the name appears in various forms including Ydée, Ydain, and the masculine forms Ydes, Ydé and Ydés. Generally speaking, the feminine forms are used when Yde is playing the female role, the masculine when she is playing the male, but such a distinction between her feminine and masculine identities is not consistently sustained in the text. In the French prose text there are no diacritics and she remains Yde throughout. Likewise Yde or Ide are the English versions of her name and they have no masculine equivalent. In the dramatic adaptation the heroine is called Ysabel and is not referred to by name when she is in her male guise.

${ }^{x x v}$ Contrast Silence who not only dresses as a man but also crosses class boundaries and disguises her/himself as a jongleur (Kinoshita 430).

${ }^{x x v i}$ In La fille d'un roy, it is Ysabel herself who comments on her female physicality when, before the bathing test, she laments that the discovery that she does not have a man's member but does have breasts will expose her as a woman (FR 2880-5).

${ }^{\text {xxvii }}$ In arguing that the poet consciously or unconsciously foregrounds grammatical indeterminacy, I do not mean to imply that the poet and/or scribe(s) do not sometimes simply become confused. In Les prouesses 
grammatical gender is equally unstable. At times it seems to reflect point of view, at others to be used for ironic effect, but becomes increasingly erratic as the narrative progresses. In the English versions some attempts seem to be made to make grammatical gender more consistent (which should be the easier since English is an analytic language) and to correct what are seen to be mistakes, but even these attempts are not sustained. Unfortunately Paris and Robert do not include editorial apparatus in their edition of the Miracles de Notre Dame: in La fille d'un roy grammatical gender appears regular but may have been silently emended. For a different perspective on the French metrical text and the English version, see Weever 386-8.

${ }^{\text {xxviii }}$ Formal constraints may have influenced the gender choices here: in the laisse in which this line appears the endings at the monorhyme or assonance are predominantly, although not exclusively, feminine.

${ }^{\text {xxix }}$ On gender as a performance that is repeated and drag as a subversive bodily act, see Butler, Gender Trouble esp. 79-149 and Bodies that Matter.

${ }^{x x x}$ Contrast Yde's response to Olive with that of Silence who is paralyzed by the advances of the queen "car nel consent pas sa nature" [“because his nature kept him from responding”] (Cornuälle, Silence, 3824).

xxxi Durling notes that these lines echo lines 3130-1 of the Iphis myth in the Ovide moralisé: “Tout n'eüst elle point de vit / Ne de membre a ce covenable" ["Although she had no penis at all / Nor member appropriate for this"] (261 n. 22). The equivalent passage to $\underline{\text { YO }} 7065-6$ in Les prouesses is less explicit. It reads "elle ne sceut quelle chose povoyt faire, car sus elle navoit membre qui ne tremblast de paour" [“she didn’t know what to do, because she had no member which did not shake with fear"] (PFM f.174r col.2). This is translated by Lord Berners as "she wyste not what to do, all her body trymbelid" ( $\underline{\mathrm{HB}}$ 723). In the play version, Ysabel lies in bed with her new wife, racked "De pensées grans et diverses / Et d'oppignions moult perverses" [by many and varied thoughts and strange opinions] (ㅍ 2559-2560).

xxxii This is an instance in which stylistic considerations have influenced the use of gender. Line 7152 is already hypermetric. A feminine l'une l'autre would render it more so, and masculine agreements on participles would not conform to the laisse. However, the French prose text (which is clearly not constrained by rhyme or meter) also reads "lung lautre", in other words masculine with feminine/masculine (PFM 174v col.2).

xxxiii "Aparler" could have metaphoric connotations of copulation and "adeser" can have the sense of "un contact charnel" (Godefroy s.v. adeser).

${ }^{\text {xxxiv }}$ The pairing of acoler and baisier is a common one (T-L s.v. $\underline{\text { acoler }}$ and baisier; Godefroy s.v. acoler,

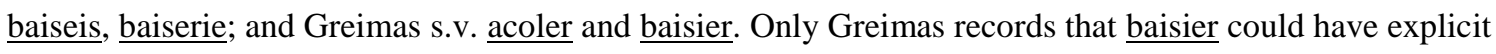
sexual connotations. These connotations are also present in the English text: for a discussion of the words 
kissen and clippen, see Watt 169. In Les prouesses, baisier and acoler are applied to the increasingly unambiguous kisses bestowed by Florent on his innocent young daughter at the start of the narrative (PFM 167r col.1). However, in Les prouesses and Huon of Burdeux baisier and acoler / kissen and clippen are used in a purely platonic context earlier in the narratives to describe the parting embraces of Yde and her governess (FM 168r col.2; $\underline{\mathrm{HB}}$ 698).

${ }^{x x x v}$ T-L s.v. taster.

${ }^{x x x v i}$ Contrast this with the example of Silence, "Quanque on en voit est trestolt malles. / El a en tine que ferine: / Il est desos le dras mescine." ["Whatever one could see was certainly male! / But there's more to this than meets the eye--(literally: there's something in the barrel besides flour) / the he's a she beneath the clothes.] (Cornuälle, Silence 2478-80). As Gaunt points out, "because she lacks a penis (and thereby the phallus), Silence can never be a man" ("Significance" 208). Yde's position is more ambiguous. Butler's discussion of the lesbian phallus in Bodies that Matter (57-91) is helpful here. According to Butler, "If a lesbian 'has' it [the phallus], it is also clar that she does not 'have' it in the traditional sense; her activity furthers a crisis in the sense of what it means to 'have' one at all" (88-9).

xxxvii In the French play Ysabel's marriage is described in strong negative terms: it is referred to by the monk who overhears Ysabel's confession to the emperor's daughter as a "chose sauvage" ["a barbarous thing"] (FR 2626). However, it is indicative that Berners translates the description of this affair as an "horreur" ["atrocity"] (PFM f.175r col.1) simply as "straunge cas" ( $\underline{\mathrm{HB}} 727)$. There is reasonably extensive evidence, especially in the early modern period, of women in France being prosecuted for sodomy - and specifically the use of prosthetic devices - as well as for dressing as men. In contrast, there is no evidence in English records of women being charged with the offense of sodomy or examined about other forms of sexual misconduct with women (c.f. Traub 152-4).

xxxviii The bathing episode is interrupted by the appearance of a stag in the palace orchard, probably a borrowing from the fourteenth-century French epic Tristan de Nanteuil, in which Blanchadine disguises herself as a man and is eventually transformed into one by God (see Hotchkiss 116-7). 